\title{
DETEKSI PEMALSUAN KOPI LUWAK MENGGUNAKAN SIFAT BIOLISTRIK DAN JARINGAN SARAF TIRUAN
}

\section{Detection of Palm Civet Coffee Adulteration using Dielectric Properties and Artificial Neural Network}

\author{
Shinta Widyaningtyas ${ }^{1 *}$, Sucipto ${ }^{1,3}$, Yusuf Hendrawan ${ }^{2}$ \\ ${ }^{1}$ Jurusan Teknologi Industri Pertanian - Fakultas Teknologi Pertanian - Universitas Brawijaya \\ Jalan Veteran - Malang 65145 \\ ${ }^{2}$ Jurusan Keteknikan Pertanian - Fakultas Teknologi Pertanian - Universitas Brawijaya \\ Jalan Veteran - Malang 65145 \\ ${ }^{3}$ Grup Riset Halal-Qualified Industry Development (Hal-QID) - Universitas Brawijaya \\ Jalan Veteran - Malang 65145 \\ *Penulis Korespondensi: email shintawidya1435@gmail.com
}

Disubmit: 23 Agustus 2018 Direvisi: 12 September 2018 Diterima: 20 September 2018

\begin{abstract}
ABSTRAK
Metode konvensional deteksi pemalsuan kopi luwak menggunakan analisis kimia bersifat destruktif, mahal, membutuhkan preparasi sampel dan waktu lama. Perancangan alat sederhana, cepat, akurat, dan non destruktif berdasarkan sifat biolistrik berpeluang untuk mendeteksi pemalsuan kopi luwak. Penelitian ini bertujuan mendapat topologi Jaringan Saraf Tiruan (JST) terbaik untuk mendeteksi pemalsuan kopi luwak menggunakan input sifat biolistrik berdasarkan total fenol, $\mathrm{pH}$, dan persentase pemalsuan kopi luwak. Hasil penelitian menunjukkan bahwa impedansi, resistansi seri, resistansi paralel berbanding terbalik dengan frekuensi, induktansi seri dan induktansi paralel berbanding lurus dengan frekuensi. Topologi JST terpilih yaitu (5-40-40-3) memiliki MSE pelatihan 0.0099 dan MSE validasi 0.0479. Hasil penelitian menunjukkan sifat biolistrik dan JST berpotensi sebagai sensor mendeteksi pemalsuan kopi luwak
\end{abstract}

Kata kunci: Akurasi; Biolistrik; Jaringan Saraf Tiruan; Kopi Luwak; Pemalsuan

\section{ABSTRACT}

Conventional method to detect adulteration in palm civet coffee using chemical analysis is destructive, expensive, requires sample preparation and need more time. Designed simple, fast, accurate, and non-destructive instrument based on bioelectric properties give chance to detect adulteration in palm civet coffee. This study aimed to get best Artificial Neural Network (ANN) topology to detect adulteration in palm civet coffee using bioelectric properties input based on total phenol, $p H$, and percentage adulteration of palm civet coffee. The result showed that impedance, series resistance, parallel resistance inversely proportional with frequencies, whereas series inductance and parallel inductance directly proportional with frequencies. Best ANN topology is (5-40-40-3) have training MSE at 0.0099 and validation MSE at 0.0479. The result showed that bioelectric properties and ANN as a potential sensor for detect adulteration of palm civet coffee

Keywords: Accuracy; Adulteration; Artificial Neural Network; Bioelectric; Palm Civet Coffee 


\section{PENDAHULUAN}

Kopi adalah bahan baku minuman yang banyak dikonsumsi dan penting bagi perekonomian negara produsen kopi. Salah satu jenis kopi dikenal mahal dan langka di dunia adalah kopi luwak (Marcone, 2004). Kopi sebagai komoditas dengan harga tinggi, kopi luwak rawan dipalsukan dengan biji kopi reguler. Saat ini belum ada metode yang diakui internasional dalam membedakan kopi luwak dan reguler. Hal ini memberi peluang perancangan peralatan sederhana, cepat, akurat, dan non destruktif yang dapat mendeteksi pemalsuan kopi luwak. Penelitian identifikasi kopi luwak telah dikembangkan oleh Ongo et al. (2012) membedakan komponen volatil kopi luwak Filipina dan kopi reguler dengan Electronic Nose dan Gas Chromatography, Jumhawan et al. (2013) menentukan senyawa pembeda kopi luwak roasted dan kopi reguler roasted dengan metode Gas Chromatography dan Quadruple Mass-Spectrometry (GC-Q/MS), Suhandy dan Yulia. (2017) kuantifikasi pemalsuan kopi reguler roasted dalam kopi luwak roasted menggunakan UV-Visible. Kelemahan utama GC-Q/MS membutuhkan biaya mahal (Sung et al., 2014; Suhandy dan Yulia., 2017; Zhang et al., 2018; Wang et al., 2019). Kelemahan electronic nose bergantung pada kondisi lingkungan seperti suhu dan kadar air yang dalam kondisi tertentu menyebabkan sensor menyimpang (Kalit et al., 2014). Hal ini membuat pengukuran sifat biolistrik bahan mengunakan metode dielektrik berpotensi sebagai sensor deteksi kopi luwak. Metode dielektrik sudah dikembangkan untuk prediksi kualitas bahan makanan dan pertanian seperti kualitas daging babi (Giraldez et al., 2010); buah kering (Alfaifi et al., 2013); air kelapa (Franco et al., 2015); penurunan kualitas minyak goreng (Yang et al., 2016); bubuk sayur kering (Ozturk et al., 2016); penambahan bahan kimia aditif dalam produk makanan cair (Nakonieczna et al., 2016).

Pada penelitian ini green beans kopi luwak dan green beans kopi reguler dibedakan berdasarkan total fenol, $\mathrm{pH}$, dan persentase pemalsuan. Asam fenolik green beans kopi Sidikalang $31.22 \mathrm{mg} / \mathrm{g}$ dan kopi Sidikalang luwak $30.87 \mathrm{mg} / \mathrm{g}$. Total polifenol green beans kopi Sidikalang 142.26 - 152.66 mgGA/g, sedangkan green beans kopi Sidikalang luwak 115.55-131.25 mg GA/g (Cheong et al., 2013). Derajat keasaman $(\mathrm{pH})$ menjadi identifikasi pemalsuan berdasarkan Kementerian Perdagangan (2013) kopi luwak rendah kafein (low caffeine), rendah keasaman (low acidity), rendah lemak (low fat), rendah rasa pahit (low bitter). Total fenol dan $\mathrm{pH}$ diduga dapat membedakan kopi luwak dan kopi reguler.

Jaringan Saraf Tiruan (JST) adalah model komputasi yang meniru struktur dan fungsi jaringan saraf biologis (Muñiz-Valencia et al., 2014; Sudha et al., 2016; Kouadio et al., 2018). Pendugaan pemalsuan kopi luwak dan kopi reguler berdasarkan total fenol, $\mathrm{pH}$, dan persentase pemalsuan menggunakan algoritma Backpropagation dengan mempertimbangkan variasi learning rate, momentum, jumlah node hidden layer dan jumlah hidden layer. Penelitian ini menggunakan green beans kopi luwak dan kopi reguler karena sekitar $75 \%$ ekspor kopi Indonesia dalam green beans (Kementerian Perdagangan, 2018). Penelitian ini bertujuan untuk mendapat topologi JST terbaik dalam menduga total fenol, $\mathrm{pH}$, dan persentase pemalsuan untuk mendukung perancangan alat pendeteksi kopi luwak.

\section{METODE}

Penelitian ini menggunakan kopi luwak arabika dan kopi reguler arabika dari PTPN XII. Kopi luwak arabika yang digunakan dalam penelitian kopi luwak tangkar. Kopi reguler arabika diolah menggunakan pengolahan cara basah. Bahan untuk membuat kapasitor plat sejajar adalah papan PCB, $\mathrm{FeCl}_{3}$, timah, dan kabel. Bahan untuk wadah bahan dielektrik adalah papan PCB dan lem.

Alat yang digunakan untuk membuat kapasitor plat sejajar adalah bor listrik, solder listrik, penggaris, dan cutter. Alat untuk membuat wadah bahan dielektrik adalah penggaris, spidol, dan cutter. Alat untuk pengukuran sifat biolistrik adalah LCR Meter HIOKI IM3523, paralel plate, dan Stavolt. Alat pengolahan data biolistrik adalah komputer Intel(R) Core(TM) i3 32 bit CPU $2.10 \mathrm{Ghz}$. Perangkat lunak yang digunakan Sistem Operasi Windows 732 bit, GUI LCR Meter HIOKI IM3523, Microsoft Excel 2010, Matlab R2012a.

Preparasi sampel dalam penelitian ini menggunakan green beans kopi luwak arabika dan green beans kopi reguler arabika sebagai objek penelitian. Setiap pengambilan 
data menggunakan 160 biji kopi, sedangkan perhitungan persentase pemalsuan dalam satuan biji. Proporsi pemalsuan yaitu $0 \%$ kopi luwak, 10\% kopi luwak, 30\% kopi luwak, 40\% kopi luwak, 50\% kopi luwak, 70\% kopi luwak, 90\% kopi luwak, 100\% kopi luwak.

Pada tahap akuisisi data sifat biolistrik, green beans pada persentase yang telah ditentukan, diletakkan di antara kapasitor plat sejajar yang telah dikalibrasi secara bergantian. Setelah itu, diukur nilai sifat biolistrik meliputi Impedansi (Z), Resistansi Seri (Rs), Resistansi Paralel (Rp), Induktansi Seri (Ls), Induktansi Paralel (Lp), pada frekuensi 2368-12000 Hz. Pengukuran nilai sifat biolistrik metode dielektrik menggunakan kapasitor plat sejajar. Menurut Icier dan Baysar. (2004), dalam kapasitor plat sejajar, bahan diletakkan diantara dua elektroda untuk membentuk kapasitor. Kelebihan dari kapasitor plat sejajar adalah murah dan akurasinya tinggi.

Optimasi topologi JST menggunakan software Matlab R2012a. Hasil akuisisi data biolistrik sebanyak 528 data tiap parameter input (Z, Ls, Lp, Rs, Rp) dan output (total fenol, $\mathrm{pH}$, persentase pemalsuan). Perancangan topologi JST terbaik melalui analisis sensitivitas dengan variasi fungsi pembelajaran; fungsi aktivasi; learning rate dan momentum $(0.1,0.5,0.9)$; hidden layer $(1,2)$; node hidden layer $(10,20,30,40)$ dengan parameter Mean Square Error (MSE) validasi terendah. Penelitian ini menggunakan 3 fungsi aktivasi yaitu fungsi linear (purelin), fungsi tan sigmoid (tansig), dan fungsi sigmoid (logsig).

\section{HASIL DAN PEMBAHASAN}

\section{Analisis Hubungan Frekuensi dan Sifat Biolistrik Terhadap Persentase Pemalsuan Kopi Luwak}

Penelitian ini menganalisis hubungan data biolistrik dan frekuensi terhadap persentase pemalsuan kopi luwak. Frekuensi berpengaruh terhadap sifat biolistrik suatu bahan karena polarisasi yang timbul dari orientasi bahan dielektrik akibat adanya medan listrik (Nelson dan Trabelsi, 2012; Liu et al., 2017; Sarma dan Mohanty, 2018). Saat frekuensi sumber tegangan eksternal diubahubah maka bahan dielektik yang disisipkan antara dua plat akan terganggu mengakibatkan perubahan arah momen dipol listrik sesuai dengan frekuensinya (Juansah, 2013).
Gambar 1 menunjukkan 100\% kopi luwak memiliki nilai impedansi terendah dan meningkat seiring bertambahnya persentase pemalsuan. Hal ini erat kaitannya dengan kadar air dalam biji kopi luwak dan reguler. Menurut Kertesz et al. (2015) perubahan impedansi dipengaruhi oleh kadar air dalam bahan. Hasil penelitian menunjukkan 100\% kopi luwak memiliki kadar air lebih tinggi dibandingkan $0 \%$ kopi luwak. Semakin rendah impedansinya, maka konduktivitas bahan semakin tinggi sehingga kadar air bahan tinggi, dan sebaliknya. Gambar 1 juga menunjukkan impedansi menurun seiring kenaikan frekuensi. Menurut Barsoukov dan Macdonald (2005) secara keseluruhan, impedansi akan menurun saat frekuensi ditingkatkan. Pengukuran impedansi juga dilakukan Wu et al. (2008) pada terung dan Vozary dan Benko. (2010) pada apel menunjukkan impedansi menurun seiring meningkatnya frekuensi.

Gambar 2 dan Gambar 3 menunjukkan induktansi meningkat seiring kenaikan frekuensi dan sebaliknya. Hasil penelitian menunjukkan induktansi bernilai negatif yang menandakan kopi bersifat kapasitif atau menyimpan muatan. Jika suatu bahan dilalui atau diberikan suatu medan listrik eksternal dan muncul suatu arus maka fenomena kemagnetan tidak dapat lepas. Adanya arus menyebabkan munculnya medan magnet walaupun efeknya sangat kecil. Berdasarkan literatur, dapat diketahui bahwa bahan biolistrik seperti kopi memiliki sifat induktif meskipun efeknya sangat kecil (Hayt dan John, 2006). Gambar 2 dan Gambar 3 induktansi $100 \%$ kopi luwak lebih rendah daripada $0 \%$ kopi luwak. Berdasarkan penelitian Juansah (2013) induktansi berkorelasi dengan tingkat kematangan buah jeruk garut dengan parameter derajat keasaman $(\mathrm{pH})$. Buah jeruk garut dengan $\mathrm{pH}$ yang rendah (asam) memiliki induktansi listrik yang besar dibandingkan buah jeruk matang. Hal ini bersesuaian dengan hasil penelitian, bahwa $\mathrm{pH}$ kopi reguler lebih rendah daripada $\mathrm{pH}$ kopi luwak.

Gambar 4 dan Gambar 5 menunjukkan resistansi menurun seiring meningkatnya frekuensi. Selain itu 100\% kopi luwak memiliki nilai resistansi terendah dibandingkan $0 \%$ kopi luwak. Hal ini dapat dianalisis melalui pendekatan kadar air. Kadar air 100\% kopi luwak lebih rendah daripada $0 \%$ kopi luwak. Air merupakan konduktor sehingga semakin tinggi kadar air maka resistansi akan rendah. 
Jurnal Teknologi Pertanian Vol. 19 No. 3 [Desember 2018] 161-172

Deteksi Pemalsuan Kopi Luwak Menggunakan Sifat Biolistrik [Widyaningtyas dkk]

Tabel 1. Trial error fungsi pembelajaran

\begin{tabular}{ccc}
\hline Fungsi Pembelajaran & MSE Pelatihan & MSE Validasi \\
\hline Traincgb & 0.98882 & 0.9783 \\
Traincgf & 0.98882 & 0.97918 \\
Traincgp & 0.98894 & 0.97936 \\
Traingd & 0.87948 & 0.96591 \\
Traingda & 0.95857 & 0.97504 \\
Traingdm & 0.97505 & 0.97733 \\
Trainlm & $\mathbf{0 . 9 8 9 1 6}$ & $\mathbf{0 . 9 8 2 0 4}$ \\
Traingdx & 0.97151 & 0.9784 \\
Trainoss & 0.98882 & 0.97811 \\
Trainrp & 0.98907 & 0.98013 \\
Trainscg & 0.9889 & 0.98062 \\
\hline
\end{tabular}

Tabel 2. Trial error fungsi aktivasi

\begin{tabular}{ccccc}
\hline \multirow{2}{*}{ Fungsi Pembelajaran } & \multicolumn{2}{c}{ Fungsi Aktivasi } & \multirow{2}{*}{ MSE Pelatihan } & \multirow{2}{*}{ MSE Validasi } \\
\cline { 2 - 3 } & Hidden Layer & Output Layer & & \\
\hline \multirow{3}{*}{ TRAINLM } & Tansig & Purelin & 0.0099 & 0.1133 \\
& Tansig & Tansig & $\mathbf{0 . 0 0 9 9}$ & $\mathbf{0 . 0 4 7 9}$ \\
& Tansig & Logsig & 0.2306 & 0.2812 \\
& Logsig & Purelin & 0.0098 & 0.0697 \\
& Logsig & Tansig & 0.0098 & 0.0806 \\
& Logsig & Logsig & 0.5291 & 0.5632 \\
\hline
\end{tabular}

Tabel 3. Akurasi dan error JST

\begin{tabular}{ccccc}
\hline$l \boldsymbol{r}$ & $\boldsymbol{m} \boldsymbol{c}$ & Topologi & MSE Pelatihan & MSE Validasi \\
\hline \multirow{4}{*}{0.1} & & $5-30-3$ & 0.01 & 0.4121 \\
& & $5-40-3$ & 0.0097 & 0.3351 \\
& 0.5 & $5-30-30-3$ & 0.0099 & 0.0954 \\
& & $5-30-40-3$ & 0.01 & 0.0514 \\
\cline { 3 - 5 } & & $5-40-40-3$ & 0.0099 & 0.0627 \\
& & $5-30-3$ & 0.01 & 0.1988 \\
0.1 & 0.9 & $5-40-3$ & 0.0099 & 0.5587 \\
& & $5-30-30-3$ & 0.0099 & 0.0544 \\
& & $5-40-30-3$ & 0.0099 & 0.0559 \\
& & $5-40-40-3$ & 0.0099 & 0.0479 \\
\hline
\end{tabular}




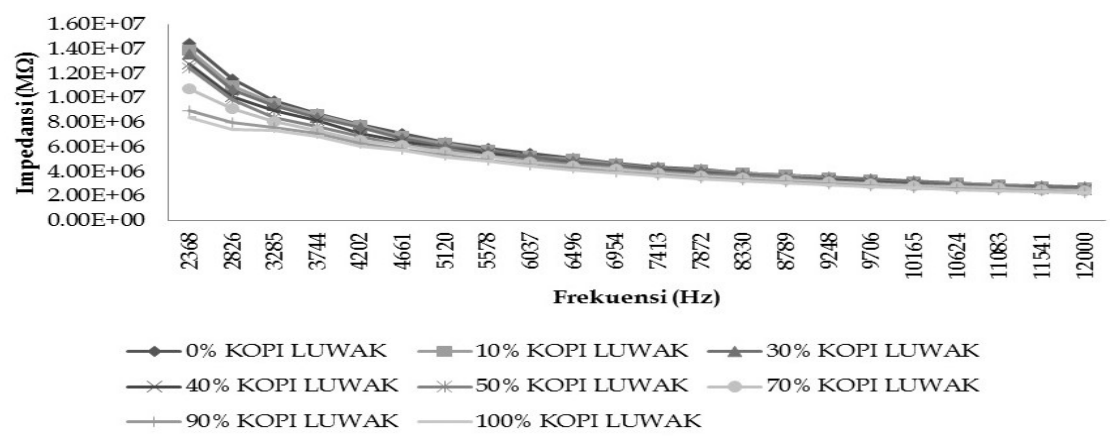

Gambar 1. Pengaruh frekuensi terhadap impedansi pada berbagai persentase pemalsuan kopi luwak

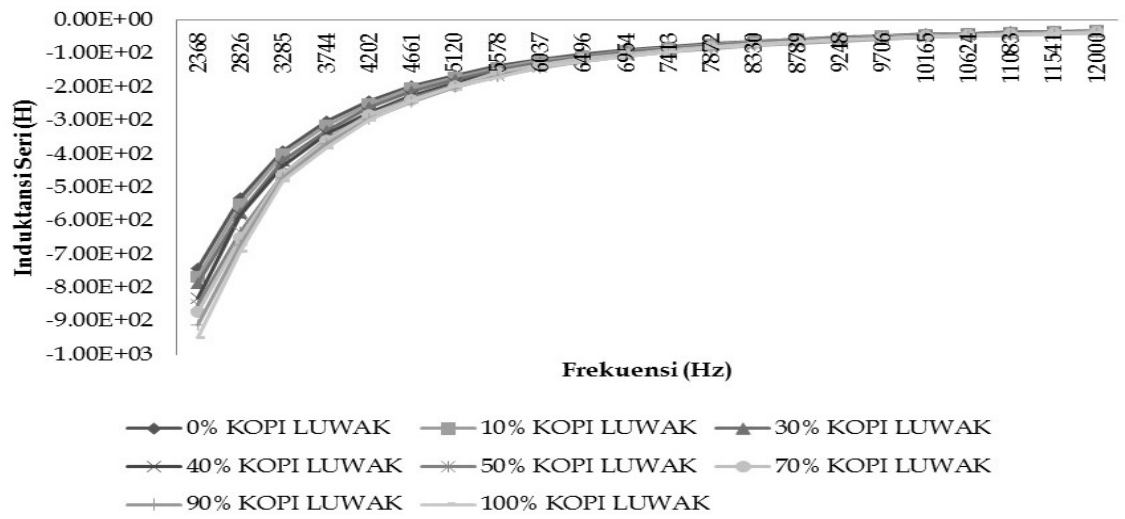

Gambar 2. Pengaruh frekuensi terhadap induktansi seri pada berbagai persentase pemalsuan kopi Luwak

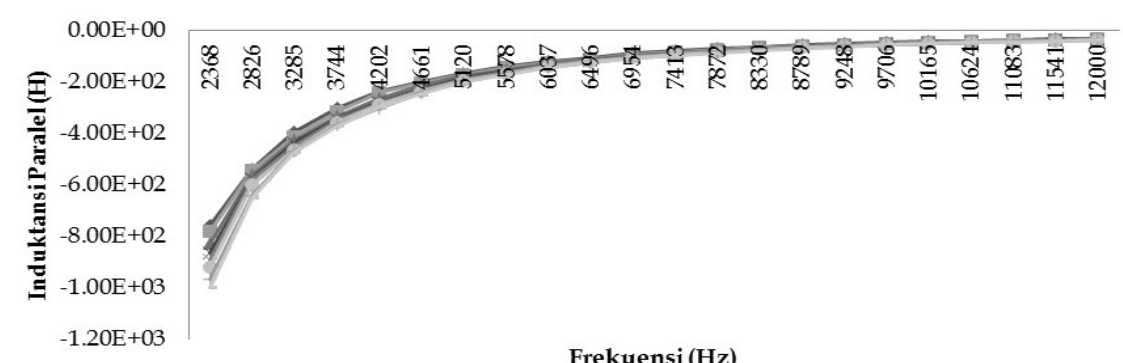

Frekuensi (Hz)

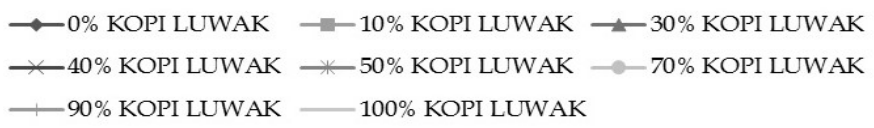

Gambar 3. Pengaruh frekuensi terhadap induktansi paralel pada berbagai persentase pemalsuan kopi luwak

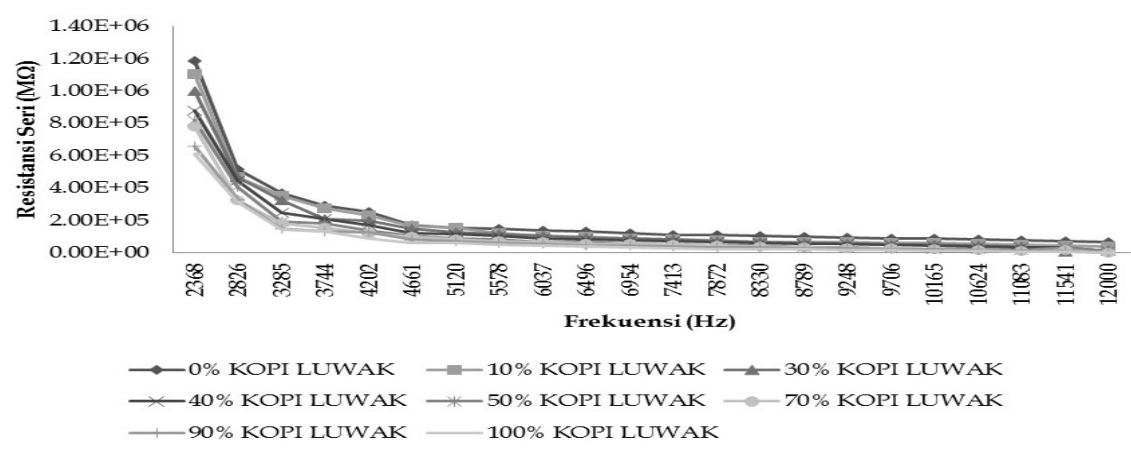

Gambar 4. Pengaruh frekuensi terhadap resistansi seri pada berbagai persentase pemalsuan kopi luwak 
Jurnal Teknologi Pertanian Vol. 19 No. 3 [Desember 2018] 161-172

Deteksi Pemalsuan Kopi Luwak Menggunakan Sifat Biolistrik [Widyaningtyas dkk]

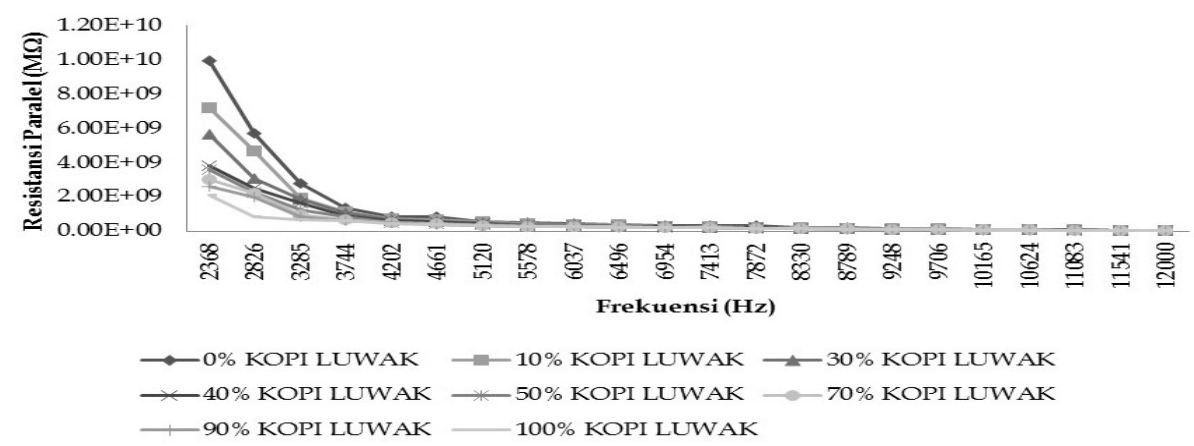

Gambar 5. Pengaruh frekuensi terhadap resistansi paralel pada berbagai persentase pemalsuan kopi luwak

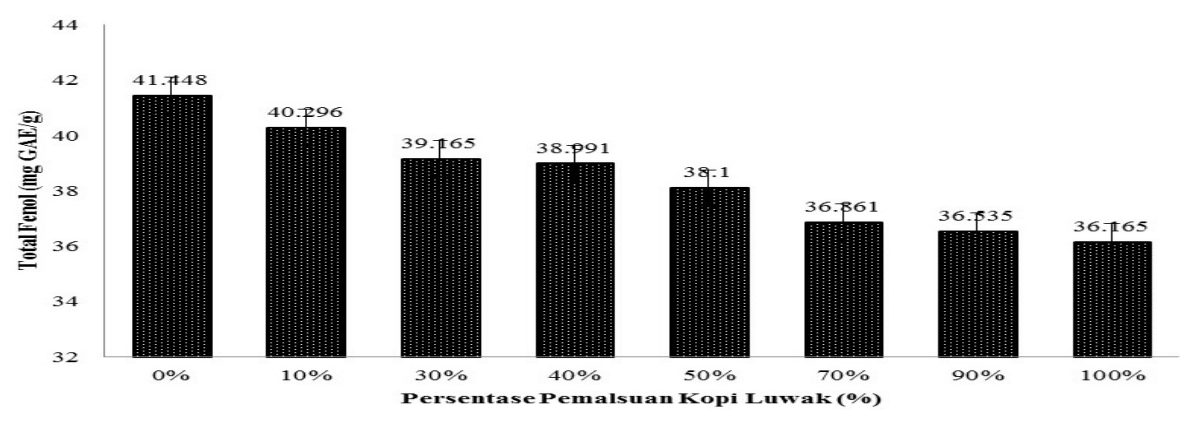

Gambar 6. Pengaruh persentase pemalsuan kopi luwak terhadap total fenol

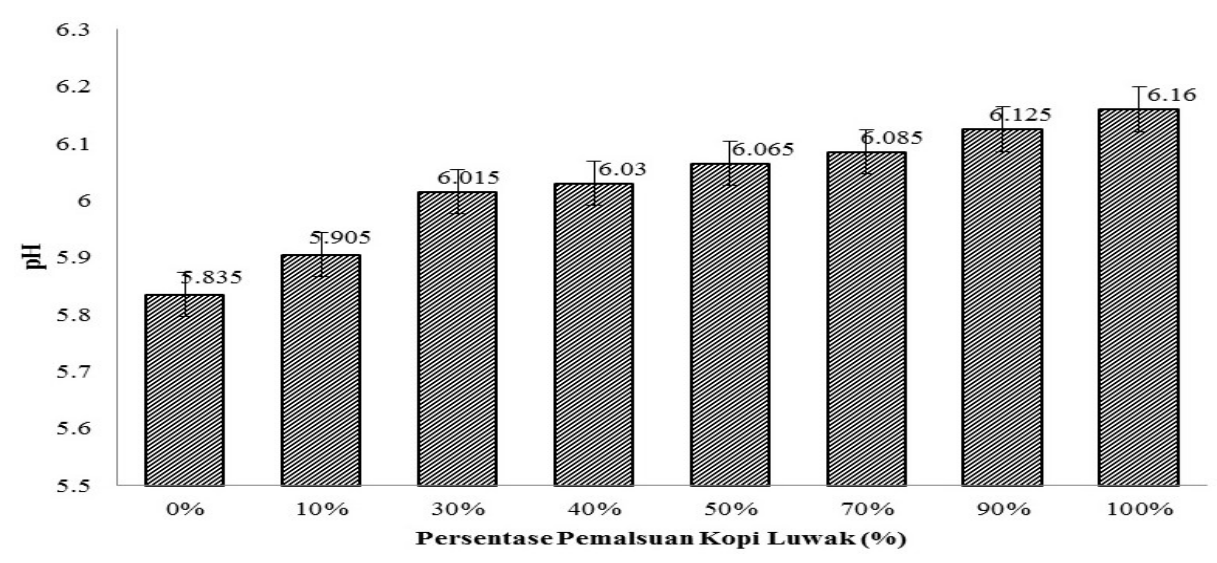

Gambar 7. Pengaruh persentase pemalsuan kopi luwak terhadap $\mathrm{pH}$

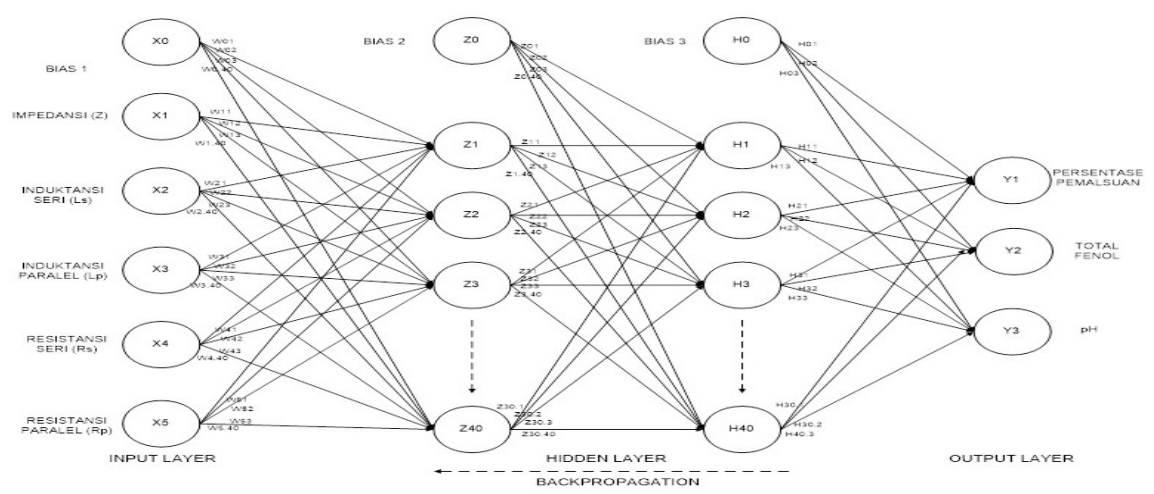

Gambar 8. Topologi JST terpilih 
Analisis Hubungan Total Fenol dan pH Terhadap Persentase Pemalsuan Kopi Luwak Gambar 6 menunjukkan total fenol meningkat seiring pertambahan kopi reguler. Asam fenolik dan total polifenol kopi Sidikalang luwak lebih rendah daripada kopi Sidikalang reguler (Cheong et al., 2013). Pada green beans kopi mengandung asam klorogenat di atas $14 \%$. Asam klorogenat merupakan bagian dari total fenol. Asam klorogenat merupakan faktor penentu kualitas kopi dan mempengaruhi aroma kopi (Carelli et al., 1974; Clifford dan Wight., 1976; Trugo dan Macrae, 1984; Variyar et al., 2003; Farah dan Donangelo, 2006). Asam klorogenat menentukan kepahitan kopi (Trugo dan Macrae, 1984; Shan et al., 2014; Meinhart et al., 2018). Penelitian Cheong et al. (2013) menunjukkan asam klorogenat green beans kopi luwak Sidikalang $30.19 \pm 0.36 \mathrm{mg} / \mathrm{g}$, sedang kopi regul- er Sidikalang $30.76 \pm 1.27 \mathrm{mg} / \mathrm{g}$. Hal ini menjadikan fenol diduga dapat membedakan kopi luwak dan reguler. Kopi luwak memiliki sifat low bitter, hal ini mendukung bahwa kadar fenol kopi luwak lebih rendah daripada reguler. Gambar 7 juga menunjukkan $\mathrm{pH}$ kopi luwak lebih tinggi dan menurun seiring pertambahan kopi reguler. Hal karena kopi luwak rendah keasaman (low acidity).

\section{Analisis Sensitivitas Perancangan Topologi Terbaik JST \\ Penelitian ini menggunakan 528 data yang diambil 22 titik dengan 3 kali ulangan pada frekuensi $2368-12000 \mathrm{~Hz}$. Data perta- ma dan ketiga digunakan sebagai pelatihan, data kedua sebagai validasi. Data biolistrik dibagi menggunakan persentase $66.667 \%$ pelatihan $-33.33 \%$ validasi. Tahap pertama dalam pelatihan JST adalah normalisasi.}

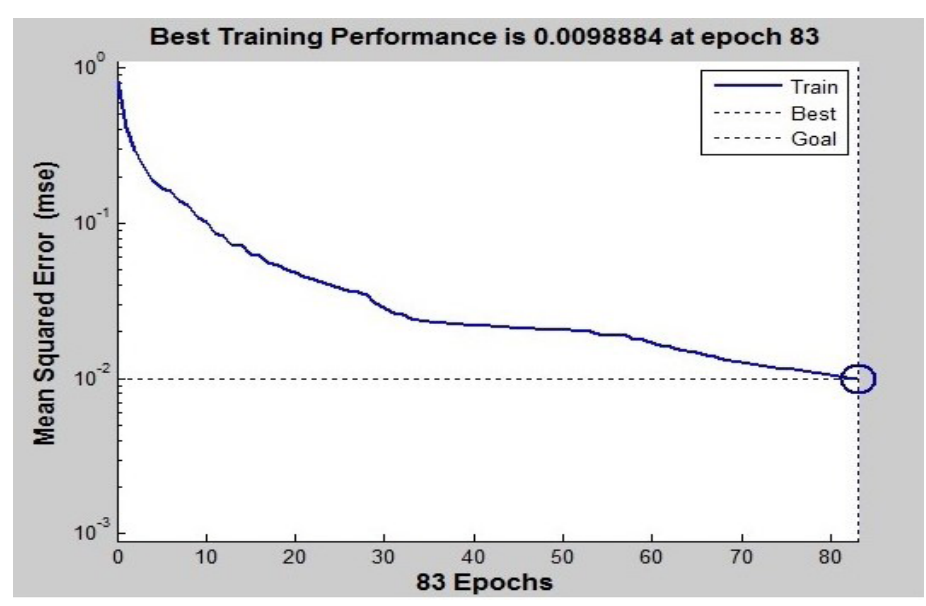

Gambar 9. Hubungan jumlah iterasi dengan MSE

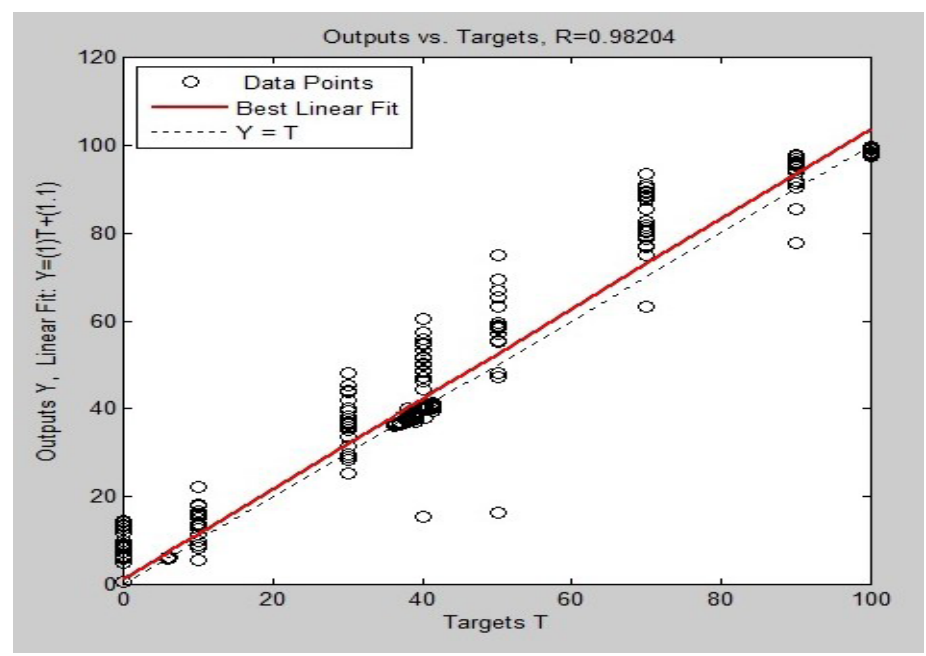

Gambar 10. Plot regresi simulasi data validasi 
Pada penelitian ini, data input dan output diubah menjadi rentang -1 sampai 1 . Normalisasi untuk menyeragamkan rentang data, menghindari perubahan bobot dan bias yang terlalu ekstrim selama pelatihan. Tahap awal dalam perancangan topologi JST adalah trial error fungsi pembelajaran. Fungsi pembelajaran berperan dalam perubahan bobot dan bias selama pelatihan. Hasil pemodelan JST adalah bobot dan bias yang mempengaruhi MSE validasi. Oleh sebab itu, trial error fungsi pembelajaran dilakukan. Hasil penelitian Torrecilla et al. (2007); Sharma dan Venugopalan. (2014); Aggarwal dan Kumar. (2015) menunjukkan fungsi pembelajaran berpengaruh terhadap kinerja JST. Penelitian ini menggunakan 14 fungsi pembelajaran. Fungsi pembelajaran terbaik dipilih berdasarkan nilai MSE validasi terendah. Tabel 1 menunjukkan fungsi pembelajaran trainlm menghasilkan MSE validasi terendah. Trainlm merupakan fungsi pembelajaran yang memperbarui bobot dan bias berdasarkan optimasi Lavenberg-Marquadt (Taghavifar dan Mardani, 2014). Algoritma trainlm menggabungkan metode steepest descent dan algoritma Gauss-Newton. Trainlm mewarisi kecepatan algoritma Gauss-Newton dan stabilitas steepest descent (Adeoti dan Osanaiye, 2013). Penggabungan dua algoritma dalam trainlm bertujuan untuk meningkatkan akurasi model dan mencapai target lebih cepat ketika error mencapai titik minimum (Li et al., 2015).

Tabel 2 menunjukkan fungsi aktivasi terbaik adalah tansig pada hidden layer dan output layer. Penelitian Chang dan Liao. (2012) menunjukkan analisis sensitivitas pada fungsi aktivasi mempengaruhi kinerja JST dalam menghasilkan MSE validasi terendah. Ketika fungsi aktivasi tidak sesuai menyebabkan kenaikan MSE.

Pada penelitian ini, perancangan topologi JST terbaik dilakukan dengan variasi learning rate (lr), momentum (mc), node hidden layer dan hidden layer. Variabel $x$ data biolistrik meliputi impedansi (Z), induktansi seri (Ls), induktansi paralel (Lp), resistansi seri (Rs), resistansi paralel (Rp) sedangkan variabel y meliputi total fenol, $\mathrm{pH}$, dan persentase pemalsuan.

Tabel 3 menunjukkan topologi 5-4040-3 dengan lr 0.1 dan mc 0.9 menghasilkan MSE validasi 0.0479. Penetapan jumlah node hidden layer dan hidden layer merupakan tahap terpenting dalam perancangan topologi
JST. Tabel 3 menunjukkan umumnya semakin banyak node hidden layer MSE validitas menurun. Topologi jaringan dengan banyak node hidden layer menghasilkan kinerja lebih baik, namun untuk beberapa permasalahan, topologi jaringan dengan sedikit node hidden layer juga dapat memberikan kinerja yang baik (Wijayasekara et al., 2011). Kompleksitas node hidden layer berbeda pada setiap permasalahan tergantung dari pola data input dan output yang digunakan. Menurut Basheer dan Hajmeer (2000) node hidden layer mempengaruhi kinerja JST karena dapat menyebabkan overfitting maupun underfitting. Overfitting menyebabkan kemampuan generalisasi menurun, sedang underfitting menyebabkan jaringan tidak mempu mendekati nilai target.

Analisis sensitivitas pada hidden layer perlu dilakukan karena hidden layer berperan menyampaikan hubungan input dan output melalui iterasi (Ahmadi et al., 2015). Hidden layer tidak berhubungan langsung dengan lingkungan namun berpengaruh signifikan terhadap output akhir (Panchal dan Panchal., 2014). Tabel 3 menunjukkan topologi dengan dua hidden layer dapat memprediksi output lebih akurat. Terkadang jaringan dengan jumlah hidden layer lebih banyak dapat mengeneralisasi lebih baik dibanding jaringan sederhana dengan jumlah hidden layer yang lebih sedikit (Dixit dan Uday, 2008). Pada penelitian ini ditetapkan jumlah hidden layer paling banyak 2, karena menurut Karsoliya (2012), dua hidden layer sudah dapat menyelesaikan masalah non linier. Topologi Artificial Neural Network terpilih dapat dilihat pada Gambar 8.

Gambar 9 menunjukkan error semakin menurun seiring bertambahnya iterasi. Hal ini karena kemampuan jaringan mengenali pola data semakin meningkat. JST merupakan model matematis yang memiliki kemampuan menghubungkan parameter input dan output, mempelajari pola data melalui iterasi tanpa mengetahui hubungan antara input dan output (Palancar et al., 1998). Pada Gambar 9, jaringan mencapai goal pada iterasi ke-83. Pada penelitian ini, jumlah iterasi maksimum 10000 dengan goal 0.01. Hal ini berarti pelatihan akan berhenti pada saat iterasi 10000 atau saat goal mencapai 0.01. Penetapan jumlah iterasi dan goal untuk menghindari overfitting model. Overfitting terjadi saat model sangat mengenali pola data pelatihan sehingga generalisasinya menurun. 
Gambar 10 menunjukkan terdapat titik sebaran data yang menyimpang dari linear fit. Hal ini menyebabkan $\mathrm{R}$ validasi rendah. Koefisien determinasi digunakan untuk mengukur seberapa jauh kemampuan model dalam menerangkan variasi variabel dependen. Besarnya koefisien determinasi berkisar 0 - 1 . Saat nilai koefisien determinasi mendekati 1 maka pengaruh variabel bebas terhadap variabel terikat sangat kuat. Berdasarkan hasil penelitian nilai $\mathrm{R}$ mendekati 1. Hal ini mengindikasikan bahwa hubungan data biolistrik (Z, Lp, Ls, Rs, Rs) terhadap total fenol, $\mathrm{pH}$, persentase pemalsuan kopi sangat kuat.

\section{SIMPULAN}

Topologi JST terpilih untuk data biolistrik yaitu 5 - $40-40-3$ (5 input, 40 node hidden layer 1, 40 node hidden layer 2, 3 output) dengan lr 0.1 dan mc 0.9, fungsi pembelajaran trainlm, fungsi aktivasi tansig pada hidden layer dan output layer. Topologi terpilih menghasilkan MSE pelatihan 0.0099 dan MSE validasi 0.0479. Input data biolistrik diantaranya impedansi $(Z)$, induktansi seri (Ls), induktansi paralel (Lp), resistansi seri (Rs), dan resistansi paralel (Rp). Sifat biolistrik dan JST berpotensi sebagai sensor dalam menduga pemalsuan kopi luwak.

\section{DAFTAR PUSTAKA}

Adeoti, O,-A., Osanaiye, P,-A., 2013. Effect of training algorithms on the performance of ANN for pattern recognition of bivariate process. Int. J. Comput. Appl. 69(20), 8-12

Aggarwal, -R., Kumar, -R., 2015. Effect of training function of artificial neural networks (ANN) on time series forecasting. Int. J. Comput. Appl. 109(3), 14-17

Ahmadi, M,-A., Soleimani, -R., Lee, -M., Kashiwao, -T., Bahadori, -A., 2015. Determination of oil well production performance using artificial neural network (ANN) linked to the particle swarm optimization (PSO) tool. Petroleum. 1(2), 118-132. https://doi. org/10.1016/j.petlm.2015.06.004
Alfaifi, -B., Wang, -S., Tang, -J., Rasco, -B., Sablani, -S., Jiao, -Y., 2013. Radio frequency disinfestation treatments for dried fruit: dielectric properties. $L W T$ Food. Sci. Technol. 50(2), 746-754. https://doi.org/10.1016/j.lwt.2012.07.012

Barsoukov, E, Macdonald, JR. 2005. Impedance Spectroscopy: Theory, Experiment and Applications. John Wiley and Sons Inc, USA

Basheer, I,-A., Hajmeer, -M., 2000. Artificial neural networks: fundamentals, computing, design, and application. J. Microbiol. Meth. 43(1), 3-31. https://doi. org/10.1016/S0167-7012(00)00201-3

Carelli, M,L,-C., Lopes, C,R,-O., Monaco, L,C., 1974. Chlorogenic acid content in species of coffea and selections of arabica. Turrialba. 24, 398-401

Chang, C,-L., Liao, C,-S., 2012. Parameter sensitivity analysis of artificial neural network for predicting water turbidity. International Journal of Environmental, Chemical, Ecological, Geological, and Geophysical Engineering. 6(10), 657-660.

Cheong, M,-W., Tong, K,-H., Ong, J,J,-M., Liu, S,-Q., Curran, -P., Yu, -B., 2013. Volatile composition and antioxidant capacity of arabica coffee. Food. Res. Int. 51(1), 388-396. https://doi. org/10.1016/j.foodres.2012.12.058

Clifford, M,-N., Wight, -J., 1976. The Measurement of feruloylquinic acids and cafeoilquinic acids in coffee beans development of the technique and its preliminary application to green coffee beans. J. Sci. Food Agric. 27, 73-84. https://doi.org/10.1002/jsfa.2740270112

Dixit, P,M., Uday, S,D. 2008. Modelling of Metal Forming and Machining Processes. Springer-Verlag, London

Farah, -A., Donangelo, C,-M., 2006. Phenolic compound in coffee. Braz. J. Plant Physicol. 18(1), 23-36. http://dx.doi. org/10.1590/S1677-04202006000100003

Franco, A,-P., Yamamoto, L,-Y., Tadini, C,-C., Gut, J,A,-W., 2015. Dielectric properties of green coconut water relevant to microwave processing: effect of temperature and field frequency. J. Food Eng. 155, 69-78. https://doi. org/10.1016/j.jfoodeng.2015.01.011

Giraldez, M,-C., Botella, -P., Toldra, -F., Fito, -P., 2010. Low-frequency dielectric spectrum to determine pork meat quality. Innov. Food. Sci. Emerg. 11(2), 376-386. https://doi.org/10.1016/j.ifset.2010.01.011 
Hayt, W,H, John, A,B. 2006. Elektromagnetika Edisi Ketujuh. Erlangga, Jakarta.

Icier, -F., Baysal, -T., 2004. Dielectric properties of food materials-2: measurement techniques. Crit. Rev. Food Sci. Nutr. 44(6), 473-478. https://doi. org/10.1080/10408690490892361

Juansah, J., 2013. Kajian Spektroskopi Impedansi Listrik untuk Evaluasi Kualitas Buah Jeruk Keprok Garut Secara Nondestruktif. Disertasi. IPB. Bogor

Jumhawan, -U., Putri, S,-P., Marwani, Y,-E., Bamba, -T., Fukusaki, -E., 2013. Selection of discriminant markers for aunthetication of asian palm civet coffee (Kopi Luwak): a metabolomics approach. J. Agric. Food. Chem. 61(33), 7994-8001. doi: 10.1021/jf401819s

Kalit, M,-T., Markovic, -K., Kalit, -S., Vahcic, -N., Havranek, -J., 2014. Application of electronic nose and electronic tongue in the dairy industry. Mljekarstvo. $64(4)$, 228-244. doi: $10.15567 / \mathrm{mlje}-$ karstvo.2014.0402

Karsoliya, S. 2012. Approximating number of hidden layer neuron in multiple hidden layer BPNN architecture. Ijetjournal. 3(6), 714-717. http://ijettjournal.org/volume-3/issue-6/IJETTV3I6P206.pdf

Kementerian Perdagangan. 2018. Peluang ekspor produk kopi di pasar kanada. Dilihat 20 Agustus 2018. <http:// djpen.kemendag.go.id/membership/ data/files/a59d6-MI-ITPC-Vancouver-2013---Kopi.pdf>

Kementerian Perdagangan. 2018. Warta ekspor pesona kopi luwak. Dilihat 21 Agustus 2018. <http:/ / djpen.kemendag.go.id/app_frontend/admin/docs/ publication/1551390367153.pdf>

Kertesz, -A., Hlavacova, -Z., Vozary, -E., Staronova, -L., 2015. Relationship between moisture content and electrical impedance of carrot slices during drying. Int. Agrophys. 29, 61-66. DOI: 10.1515/intag-2015-0013

Kouadio, -L., Deo, R,-C., Byarareddy, -V., Adamowski, J, -F., Mushtaq, -S., Nguyen, V, -P., 2018. Artificial intelligence approach for the prediction of Robusta coffee yield using soil fertility properties. Computers and Electronics in Agriculture. 155, 324-338. https:// doi.org/10.1016/j.compag.2018.10.014

Li, -X., Chen, -F., Sun, -D., Tao, -M., 2015. Pre- dicting menopausal symptoms with artificial neural network. Expert Syst Appl. 42(22), 8698-8706. doi $>10.1016 / j$. eswa.2015.07.024

Liu, -J., Wang, -X., Wang, -Z., Lu, -Y., Li, -X., Ren, -Y., 2017. Integrating microbial fuel cells with anaerobic acidification and forward osmosis membrane for enhancing bio-electricity and water recovery from low-strength wastewater. Water Research. 110, 74-82. https://doi. org/10.1016/j.watres.2016.12.012

Marcone, M,-F., 2004. Composition and properties of indonesian palm civet coffee (Kopi Luwak) and ethiopian civet coffee. Food. Res. Int. 37(9):901-912. https:/ / doi.org/10.1016/j.foodres.2004.05.008

Meinhart, A, -D., Caldeirão, -L., Damin, F, -M., Filho, J, -T., Godoy, H, -T., 2018. Analysis of chlorogenic acids isomers and caffeic acid in 89 herbal infusions (tea). Journal of Food Composition and Analysis. 73, 76-82. https://doi. org/10.1016/j.jfca.2018.08.001

Muñiz-Valencia, -R., Jurado, J,-M., CeballosMagaña, -S,-G., Alcázar, -A., Hernández-Díaz, -J., 2014. Characterization of Mexican coffee according to mineral contents by means of multilayer perceptrons artificial neural networks. Journal of Food Composition and Analysis. 34(1),7-11. https://doi.org/10.1016/j. jfca.2014.02.003

Nakonieczna, -A., Paszkowski, -B., Wilczek, -A., Szyplowska, -A., Skierucha, -W., 2016. Eletrical impedance measurements for detecting artificial chemical additives in liquid food products. Food Control. 66, 116-129. https://doi. org/10.1016/j.foodcont.2016.01.044

Nelson, S,-O., Trabelsi, -S., 2012. Factors Influencing the dielectric properties of agricultural and food products. J. Microw. Power. Electromagn. Energy. 46(2), 93-107. doi:10.13031/2013.41891

Ongo, -E., Falasconi, -M., Sberveglieri, -G., Antonelli, -A., Montevecchi, -G., Sberveglieri, -V., Concina, -I., Sevilla III, -F., 2012. Chemometric discrimination of phillipine civet coffee using electronic nose and gas chromatography mass spectrometry. Procedia Engineering. 47, 977-980. https://doi. org/10.1016/j.proeng.2012.09.310

Ozturk, -S., Kong, -F., Trabelsi, -S., Singh, R,-K., 2016. Dielectric properties of 
dried vegetable powders and their temperature profile during radio frequency heating. J. Food Eng. 169, 91100. https://doi.org/10.1016/j.jfoodeng.2015.08.008

Palancar, M,-C, Aragon, J,-M, Torrecilla, J,-S. 1998. $\mathrm{pH}$ control system based on artificial neural networks. Ind. Eng. Chem. Res. 37(7), 2729-2740. DOI: 10.1021/ie970718w

Panchal, F,-S., Panchal, -M., 2014. Review on method of selecting number of hidden nodes in artificial neural network. IJCSMC. 3(11), 455-464. https://www. ijcsmc.com/docs/papers/November2014/V3I11201499a19.pdf

Sarma, P, -J., Mohanty, -K., 2018. Epipremnum aureum and Dracaena braunii as indoor plants for enhanced bio-electricity generation in a plant microbial fuel cell with electrochemically modified carbon fiber brush anode. Journal of Bioscience and Bioengineering. 126(3), 404-410. https://doi.org/10.1016/j. jbiosc.2018.03.009

Shan, -J., Suzuki, -T., Suhandy, -D., Ogawa, -Y., Kondo, -N., 2014. Chlorogenic acid (CGA) determination in roasted coffee beans by Near Infrared (NIR) spectroscopy. Engineering in Agriculture, Environment and Food. 7(4), 139-142. https://doi.org/10.1016/j. eaef.2014.08.003

Sharma, -B., Venugopulan, -K., 2014, Comparison of neural network training functions for hematoma classification in brain CT images. IOSR-JCE. 16(1), 31-35. https://pdfs.semanticscholar.org/14ac/e90f795e7b463d0168883d671e044f5c8375.pdf

Sudha, -L., Dillibabu, -R., Srinivas, S, -S., Annamalai, -A., 2016. Optimization of process parameters in feed manufacturing using artificial neural network. Comput. Electron Agr. 120, 1-6. https:// doi.org/10.1016/j.compag.2015.11.004

Suhandy, -D., Yulia, -M., 2017. The use of partial least square regression and spectral data in uv-visible region for quantification of adulteration in indonesian palm civet coffee. International Journal of Food Science. 2017(1), 1-7. https://doi.org/10.1155/2017/6274178

Sung, -J., Kim, B, -K., Kim, B, -S., Kim, -Y., 2014. Mass spectrometry-based electric nose system for assessing rice quality during storage at different temperatures. Journal of Stored Products Research. 59, 204-208. https:// doi.org/10.1016/j.jspr.2014.02.009

Taghavifar, -H., Mardani, -A., 2014. Application of artificial neural networks for the prediction of traction performance parameters. Journal of the Saudi Society of Agricultural Sciences. 13(1), 35-43. https:// doi.org/10.1016/j.jssas.2013.01.002

Torrecilla, J,-S., Otero, -L., Sanz, P,-D., 2007. Optimization of an artificial neural network for thermal/pressure food processing: evaluation of training algorithms. Comput. Electron Agr. 56(2), 101-110. https://doi.org/10.1016/j. compag.2007.01.005

Trugo, L,-C., Macrae, -R., 1984. A study of the effect of roasting on the chlorogenic acid composition of coffee using HPLC. Food Chem. 15(3), 219-227. https:/ / doi. org/10.1016/0308-8146(84)90006-2

Variyar, P,-S., Ahmad, -R., Bhat, -R., Niyas, -Z., Sharma, -A., 2003. Flavoring components of raw monsooned arabica coffee and their changes during radiation processing. J. Agric. Food. Chem. 51, 7945-7950. DOI: 10.1021/ jf030408q

Vozary, -E., Benko, -P., 2010. Non-destructive determination of impedance spectrum of fruit flesh under the skin. J. Phys. Conf. Ser. 224(1), 1-4. http://iopscience.iop.org/article/10.1088/1742-6596/224/1/012142

Wang, -Q., Li, -L., Ding, -W., Zhang, -D., Wang, -J., Reed, -K., Zhang, -B., 2019. Adulterant identification in mutton by electronic nose and gas chromatography-mass spectrometer. Food Control. 198, 431-438. https://doi. org/10.1016/j.foodcont.2018.11.038

Wijayasekara, -D., Manic, -M., Sabharwall, -P., Utgikar, -V., 2011. Optimal artificial neural network architecture selection for performance prediction of compact heat exchanger with the EBaLM-OTR technique. Nucl Eng Des. 241(7), 25492557. https://doi.org/10.1016/j.nucengdes.2011.04.045

Wu, -L., Ogawa, -Y., Tagawa, -A., 2008. Electrical impedance spectroscopy analysis of eggplant pulp and effects of drying and freezing-thawing treatments on its impedance characteristics. J. Food Eng. 87(2):274-280. https://doi. org/10.1016/j.jfoodeng.2007.12.003 
Jurnal Teknologi Pertanian Vol. 19 No. 3 [Desember 2018] 161-172

Deteksi Pemalsuan Kopi Luwak Menggunakan Sifat Biolistrik [Widyaningtyas dkk]

Yang, -J., Zhao, K,-S., He, Y,-J., 2016. Quality evaluation of frying oil deterioration by dielectric spectroscopy. J. Food Eng. 180, 69-76. https://doi.org/10.1016/j. jfoodeng.2016.02.012
Zhang, -X., Cheng, -J., Wu, -L., Mei, -Y., Jaffrezic-Renault, -N., Guo, -Z., 2018. An overview of an artificial nose system. Talanta. 184, 93-102. https://doi. org/10.1016/j.talanta.2018.02.113 